\title{
The atrial fibrillation prescription
}

\author{
Marc Gillinov, MD, and Edward G. Soltesz, MD, MPH
}

\footnotetext{
From the Department of Thoracic and Cardiovascular Surgery, Cleveland Clinic, Cleveland, Ohio.

Disclosures: Dr Gillinov has served as a consultant to AtriCure and Medtronic. Dr Soltesz has served as a consultant to AtriCure. Cleveland Clinic has the right to receive royalties from AtriCure related to sales of a device for left atrial appendage occlusion.

Received for publication Sept 13, 2017; accepted for publication Sept 16, 2017; available ahead of print Oct 24, 2017.

Address for reprints: Marc Gillinov, MD, Department of Thoracic and Cardiovascular Surgery, Cleveland Clinic, 9500 Euclid Ave, Desk J4-1, Cleveland, OH 44195 (E-mail: gillinom@ccf.org).

J Thorac Cardiovasc Surg 2018;155:157-8

$0022-5223 / \$ 36.00$

Copyright (C) 2017 by The American Association for Thoracic Surgery

https://doi.org/10.1016/j.jtcvs.2017.09.077
}

When Dr James Cox devised the Cox-Maze III procedure, he presented cardiac surgeons with a remarkably effective operation that was based on extensive scientific inquiry and experimentation. Although clinical series quickly confirmed excellent operative results, uptake by surgeons was remarkably slow. Surgeons' reluctance to perform the operation was understandable; the cut-and-sew Cox-Maze III procedure was both complex and time-consuming. The majority of surgeons glanced at diagrams depicting the lesion sets and decided not to add this extensive undertaking to the patient's primary valve or coronary artery surgery. At that time, this choice was reasonable. In contrast, the decision to forego surgical ablation in contemporary practice is far more difficult to understand, and the work of Musharbash and colleagues ${ }^{1}$ in this issue of the Journal lends further support to the imperative that we broaden our application of surgical ablation.

\section{THE BENEFITS OF SURGICAL ABLATION}

Cardiac surgeons operate to save lives. Patients with aortic stenosis, mitral regurgitation, and coronary artery disease live longer after a successful operation. Musharbash and colleagues ${ }^{1}$ demonstrate that the same holds true for patients with atrial fibrillation; long-term survival is improved by concomitant surgical ablation. This finding echoes previous reports. ${ }^{2}$ In addition to its favorable impact on survival, ablation has been associated with decreased risk of stroke, reduced need for long-term anticoagulation and the attendant risk of bleeding, and improved quality of life. ${ }^{3}$ These benefits likely stem from a combination of rhythm control and management of the left atrial appendage. Although this particular study does not address heart rhythm after surgical ablation, previous reports from this group and others confirm 5-year freedom from atrial fibrillation in the range of $70 \%$ to $80 \%{ }^{4}$ In short, the operation is effective at controlling heart rhythm and beneficial in its clinical effects.

\section{THE RISKS OF SURGICAL ABLATION}

Surgical ablation is a safe procedure. Although a CoxMaze IV procedure adds 20 to 40 minutes to the aortic

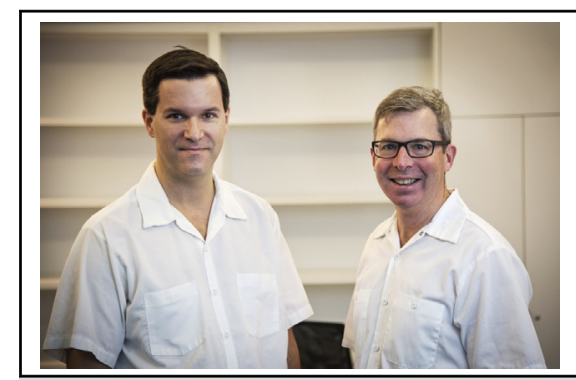

Marc Gillinov, MD, and Ed Soltesz, MD, MPH

\section{Central Message}

In cardiac surgical patients with atrial fibrillation, the Cox-Maze IV procedure provides rhythm control and increases long-term survival. There is only one remaining mystery concerning this procedure: why are surgeons reluctant to use it?

See Article page 159.

crossclamp time, this is generally well tolerated. Confirming previous results, the authors of this study found no increase in major morbidity or mortality in patients who received surgical ablation. Nonetheless, surgical ablation does have some costs. Compared with patients whose atrial fibrillation was left untreated, patients undergoing surgical ablation were more likely to receive a permanent pacemaker and to have longer intensive care unit and hospital lengths of stay. Although these costs cannot be considered negligible, the clinical benefits of surgical ablation far outweigh these factors.

\section{THE OPERATION}

Musharbash and colleagues ${ }^{1}$ report the results achieved with a standardized approach to ablation: the Cox-Maze IV. As they note, this operation represents the current gold standard for surgical ablation. Incorporating bipolar radiofrequency and/or cryothermy, the biatrial lesion set of the Cox-Maze IV procedure produces the benefits enumerated earlier. It is unclear whether other procedures, particularly pulmonary vein isolation alone, confer the same benefits to the patient. Therefore, surgeons' default should be the energy-assisted, biatrial lesion set of the Cox-Maze IV.

\section{THE MYSTERY}

According to the Society of Thoracic Surgeons database, fewer than one half of cardiac surgery patients with atrial fibrillation undergo concomitant ablation. ${ }^{5}$ In fact, in the 
current series from Washington University, only one quarter of patients with preexisting atrial fibrillation had ablation. Surgeons clearly use some sort of selection process in patients with atrial fibrillation, and, in the majority of patients, elect to forego ablation. Herein lies the real mystery with surgical ablation. Most of the questions concerning safety, effectiveness, and clinical benefits have been answered. The remaining question is this: why don't surgeons do this operation more frequently?

\section{References}

1. Musharbash FN, Schill MR, Sinn LA, Schuessler RB, Maniar HS, Moon MR, et al. Performance of the Cox-Maze IV procedure is associated with improved long- term survival in patients with atrial fibrillation undergoing cardiac surgery. $J$ Thorac Cardiovasc Surg. 2018:155:159-70.

2. Lee R, McCarthy PM, Wang EC, Vaduganathan M, Kruse J, Malaisrie SC, et al. Midterm survival in patients treated for atrial fibrillation: a propensity-matched comparison to patients without a history of atrial fibrillation. J Thorac Cardiovasc Surg. 2012;143:1341-51; discussion 1350-1.

3. Ad N, Cheng DCH, Martin J, Berglin EE, Chang BC, Doukas G, et al. Surgical ablation for atrial fibrillation in cardiac surgery: a consensus statement of the International Society of Minimally Invasive Cardiothoracic Surgery (ISMICS) 2009. Innovations. 2010;5:74-83.

4. Henn MC, Lancaster TS, Miller JR, Sinn LA, Schuessler RB, Moon MR, et al. Late outcomes after the Cox-Maze IV procedure for atrial fibrillation. $J$ Thorac Cardiovasc Surg. 2015;150:1168-76.

5. Ad N, Suri RM, Gammie JS, Sheng S, O'Brien SM, Henry L. Surgical ablation of atrial fibrillation trends and outcomes in North America. J Thorac Cardiovasc Surg. 2012;144:1051-60.

Access to The Journal of Thoracic and Cardiovascular Surgery Online is reserved for print subscribers!

Full-text access to The Journal of Thoracic and Cardiovascular Surgery Online is available for all print subscribers. To activate your individual online subscription, please visit The Journal of Thoracic and Cardiovascular Surgery Online, point your browser to http://www.mosby.com/jtcvs, follow the prompts to activate your online access, and follow the instructions. To activate your account, you will need your subscriber account number, which you can find on your mailing label (note: the number of digits in your subscriber account number varies from 6 to 10). See the example below in which the subscriber account number has been circled:

\section{Sample mailing label}

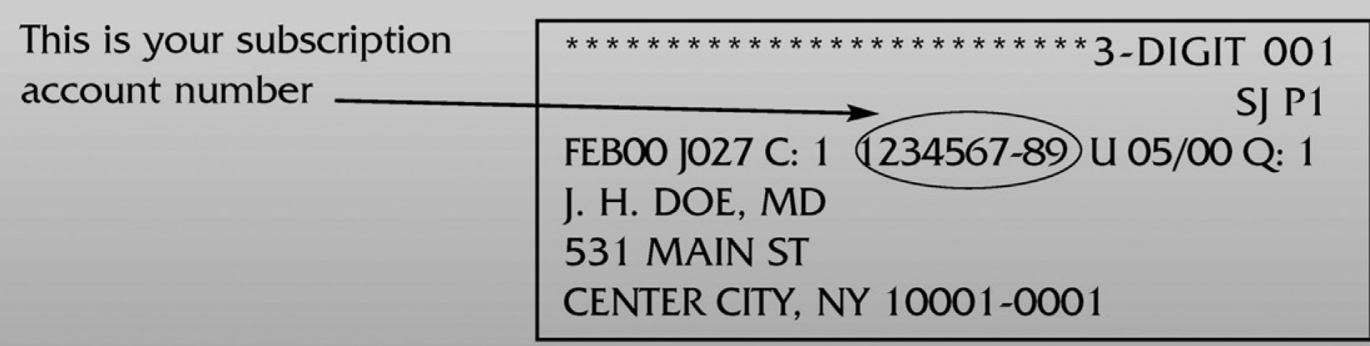

Personal subscriptions to The Journal of Thoracic and Cardiovascular Surgery Online are for individual use only and may not be transferred. Use of The Journal of Thoracic and Cardiovascular Surgery Online is subject to agreement to the terms and conditions as indicated online. 